\title{
ASSESSMENT FOR THE NECESSITY TO CHANGE UNDERGRADUATE PHARMACOLOGY CURRICULUM IN MEDICAL COLLEGES: A QUESTIONNAIRE BASED STUDY
}

\author{
Sabnam Ara Begum¹, Munmun Mukherjee2, Mausumi De3, Anup Kumar Das', Avijit Ganguly5, Tapabrato Guha Ray6 \\ ${ }_{1}^{1}$ Assistant Professor, Department of Pharmacology, R. G. Kar Medical College, Kolkata, West Bengal. \\ ${ }_{2}^{2}$ Post Graduate Trainee, Department of Pharmacology, R. G. Kar Medical College, Kolkata, West Bengal. \\ ${ }^{3}$ Associate Professor, Department of Pharmacology, R. G. Kar Medical College, Kolkata, West Bengal. \\ ${ }^{4}$ Professor and HOD, Department of Pharmacology, R. G. Kar Medical College, Kolkata, West Bengal. \\ 5 Post-Doctoral Trainee, Department of Clinical and Experimental Pharmacology, Calcutta School of Tropical Medicine, Kolkata. \\ ${ }^{6}$ Associate Professor, Department of Community Medicine, R. G. Kar Medical College, Kolkata, West Bengal.
}

\section{ABSTRACT}

\section{BACKGROUND}

Pharmacology forms the backbone of rational therapeutics. The primary objective of teaching pharmacology is to enable undergraduate medical students to prescribe rationally. Hence, a survey was carried out at Medical Colleges of West Bengal to assess whether any change is needed in Pharmacology curriculum.

\section{MATERIALS AND METHODS}

This is a cross-sectional study involving junior doctors (house staffs, interns), faculty members of Pharmacology and clinicians of Medical Colleges of West Bengal in Kolkata, who were surveyed with 14 validated questionnaires which were designed based on internationally accepted "Likert Scale." A study was carried out involving ninety participants. Analysis was based on proportion and percentage wise distribution of various parameters used in the questionnaire.

\section{RESULTS}

In this study faculty member of pharmacology, clinicians and junior doctors who participated were ninety in number; $96.5 \%$ clinicians and $93.4 \%$ pharmacologists were in favour of bed side case study and integration of pharmacology with other clinical subjects; $93.1 \%$ clinicians and $93.3 \%$ pharmacologists were in favour of teaching some topics of pharmacology in final year again; 97\% clinicians and $96.7 \%$ pharmacologists were in favour of partial handouts before lectures; $89.7 \%$ clinicians and $100 \%$ pharmacologists felt that improved training could have prevented adverse drug reaction.

\section{CONCLUSION}

So in this study, we evaluated that all the three groups are in favour of modification of undergraduate curriculum.

\section{KEYWORDS}

Existing Pharmacology Curriculum, Proposed Curriculum, Validated Questionnaires, Likert Scale, Rational Prescription.

HOW TO CITE THIS ARTICLE: Begum SA, Mukherjee M, De M, et al. Assessment for the necessity to change undergraduate pharmacology curriculum in medical colleges: a questionnaire based study. J. Evolution Med. Dent. Sci. 2016;5(46):2855-2859, DOI: $10.14260 /$ jemds/2016/666

\section{INTRODUCTION}

Pharmacology is the subject which has got scientific obligation and internal medicine is the subject which has got social and monetary obligation. ${ }^{1}$ Applied pharmacology is the knowledge for rational and judicious use of right drug, in the right form, right dosage schedule, right inter-dose interval, right duration and for the right cause with background knowledge of mechanism of action and adverse reaction of drug. ${ }^{1}$

Pharmacology, a branch of medicine is progressing by leaps and bounds. Consequently, reforms in pharmacology are the need of the hour. ${ }^{2}$ The objective of teaching pharmacology to undergraduate students can be fulfilled only if they are well acquainted with the subject with respect to innovations in this field.

This needs continuous review and modifications in teaching methodology and evaluation methods in pharmacology.

\section{Financial or Other, Competing Interest: None}

Submission 17-04-2016, Peer Review 18-05-2016,

Acceptance 25-05-2016, Published 07-06-2016.

Corresponding Author:

Dr. Avijit Ganguly,

BG 116, Rabindrapally,

Krishnapur, P.O. Prafullakanan,

Kolkata-700101.

E-mail: avijitdec81@gmail.com

DOI: $10.14260 /$ jemds/2016/666
Many reforms have been made in undergraduate teaching of pharmacology in different institutions. Clinical pharmacology, group discussions and practical classes on therapeutic problems are being introduced. Didactic lectures have decreased. Pharmacology is at crossroads. The place and status of pharmacology in the medical curriculum is hazy.

Considering all these facts, it was decided to get a general feedback from the pharmacologists, clinical tutors, intern and house staffs about the subject with respect to its: a) Current teaching methods, b) Its usefulness in clinics and thereby adopt certain changes if necessary.

\section{The Primary Objective of Teaching Pharmacology is to}

1. Enable undergraduate medical students to take rational therapeutic decisions in clinical practice.

2. To check whether knowledge of the study subjects have adequate knowledge of Pharmacology subject to apply in day-to-day practice.

Studies found on the feeling of clinicians in use of drugs on the knowledge obtained from existing pharmacology curriculum.

A survey was carried out in teaching hospitals of West Bengal to assess whether any change is needed in undergraduate pharmacology curriculum. Pharmacologists, clinical tutors and junior doctors selected as study population, because pharmacologists distribute knowledge of medicine, 
clinical tutors apply those knowledge and junior doctors have first-hand experience. Objective of this study is to assess whether an imperative need to change undergraduate pharmacology curriculum to enable the medical graduates to prescribe the drug rationally, safely and confidently.

\section{METHODOLOGY}

This is a cross-sectional observational study. Institutional Ethics Committee of R. G. Kar Medical College gave permission to conduct the study. Before the original study, a pilot study has been done on 15 subjects. Total 90 subjects have been taken as a study population, 30 pharmacologists, 30 clinical tutors and 30 junior doctors. Total study period was 3 months. Subjects are given 14 validated questions for response. Questions are based on 5 point "Likert" scale. (SA=Strongly agree, $A=$ Agree, $N S=$ Not sure, $D=$ Disagree, $S D A=$ Strongly disagree). Questionnaire (Annexure A) based on existing system of teaching and proposed curriculum. Analysis was done on SPSS version 20 proportion and percentage wise distribution of parameter.

\section{RESULT}

For the existing system of curriculum in the questions whether pharmacology equipped me to prescribe rationally $70 \%$ pharmacologists agreed and 13.3\% strongly agreed, 60\% junior doctors agreed and 10\% strongly agreed, whereas $48.3 \%$ clinical tutors not sure and $17.2 \%$ totally disagree. Here, $\mathrm{p}$ value is $<0.05$. There is significant difference.

\begin{tabular}{|c|c|c|c|c|c|c|}
\hline & \multicolumn{3}{|c|}{ Participant } & \multirow{3}{*}{$\begin{array}{c}\text { Total } \\
48\end{array}$} \\
\hline & & & C & $\mathbf{H}$ & $\mathbf{P}$ & \\
\hline \multirow{8}{*}{ Q1 } & \multirow[b]{2}{*}{ A } & Count & 9 & 18 & 21 & \\
\hline & & $\begin{array}{c}\text { \% within } \\
\text { Participant }\end{array}$ & $31.0 \%$ & $60.0 \%$ & $70.0 \%$ & $53.9 \%$ \\
\hline & \multirow[b]{2}{*}{ D } & Count & 5 & 1 & 0 & 6 \\
\hline & & $\begin{array}{c}\% \text { within } \\
\text { Participant }\end{array}$ & $17.2 \%$ & $3.3 \%$ & $0.0 \%$ & $6.7 \%$ \\
\hline & \multirow[b]{2}{*}{ NS } & Count & 14 & 8 & 5 & 27 \\
\hline & & $\begin{array}{c}\% \text { within } \\
\text { Participant }\end{array}$ & $48.3 \%$ & $26.7 \%$ & $16.7 \%$ & $30.3 \%$ \\
\hline & \multirow[b]{2}{*}{ SA } & Count & 1 & 3 & 4 & 8 \\
\hline & & $\begin{array}{c}\text { \% within } \\
\text { Participant }\end{array}$ & $3.4 \%$ & $10.0 \%$ & $13.3 \%$ & $9.0 \%$ \\
\hline \multirow{2}{*}{\multicolumn{2}{|c|}{ Total }} & Count & 29 & 30 & 30 & 89 \\
\hline & & $\begin{array}{c}\text { \% within } \\
\text { Participant }\end{array}$ & $100.0 \%$ & $100.0 \%$ & $100.0 \%$ & $100.0 \%$ \\
\hline
\end{tabular}

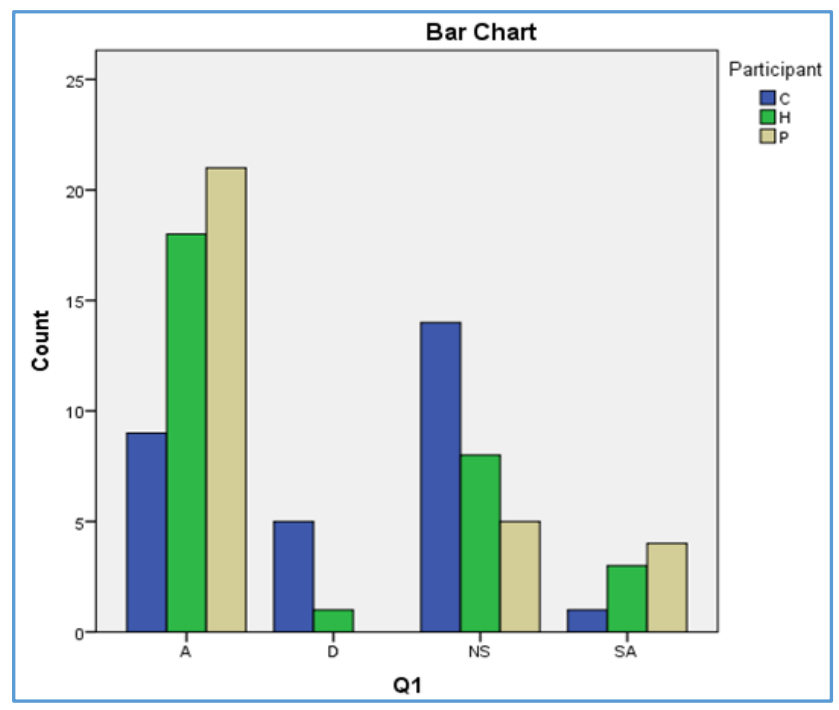

Fig. 1
In the question of knowledge about drug used in medical emergency $65.5 \%$ clinical tutors agreed, $43.3 \%$ pharmacologists agreed, $53.3 \%$ junior doctors are not sure. Here also, $\mathrm{p}$ value is $<0.05 \%$. In question of use of antidote in drug overdose, $50 \%$ junior doctors and $46.7 \%$ pharmacologists agreed, whereas $51.7 \%$ clinicians are not sure.

\begin{tabular}{|c|c|c|c|c|c|c|}
\hline & \multicolumn{3}{|c|}{ Participant } & \multirow{3}{*}{$\begin{array}{c}\text { Total } \\
40\end{array}$} \\
\hline & & & C & $\mathbf{H}$ & $\mathbf{P}$ & \\
\hline \multirow{8}{*}{ Q3 } & \multirow[b]{2}{*}{ A } & Count & 11 & 15 & 14 & \\
\hline & & $\begin{array}{c}\% \text { within } \\
\text { Participant }\end{array}$ & $37.9 \%$ & $50.0 \%$ & $46.7 \%$ & $44.9 \%$ \\
\hline & \multirow[b]{2}{*}{ D } & Count & 3 & 0 & 1 & 4 \\
\hline & & $\begin{array}{c}\% \text { within } \\
\text { Participant }\end{array}$ & $10.3 \%$ & $0.0 \%$ & $3.3 \%$ & $4.5 \%$ \\
\hline & \multirow[b]{2}{*}{ NS } & Count & 15 & 8 & 11 & 34 \\
\hline & & $\begin{array}{c}\text { \% within } \\
\text { Participant }\end{array}$ & $51.7 \%$ & $26.7 \%$ & $36.7 \%$ & $38.2 \%$ \\
\hline & \multirow[b]{2}{*}{ SA } & Count & 0 & 7 & 4 & 11 \\
\hline & & $\begin{array}{c}\% \text { within } \\
\text { Participant }\end{array}$ & $0.0 \%$ & $23.3 \%$ & $13.3 \%$ & $12.4 \%$ \\
\hline \multirow{2}{*}{\multicolumn{2}{|c|}{ Total }} & Count & 29 & 30 & 30 & 89 \\
\hline & & $\begin{array}{c}\% \text { within } \\
\text { Participant }\end{array}$ & $100.0 \%$ & $100.0 \%$ & $100.0 \%$ & $100.0 \%$ \\
\hline
\end{tabular}

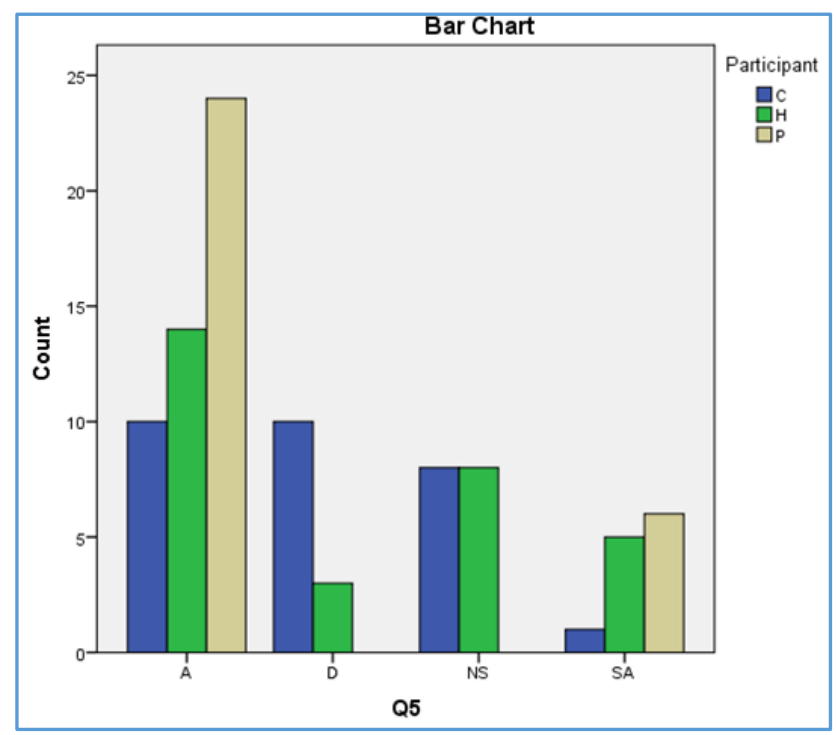

Fig. 2

Regarding consulting text book of concerned subjects during difficulty in prescribing some drugs - all the three groups agreed, but clinical tutors and junior doctors strongly agreed.

\begin{tabular}{|c|c|c|c|c|c|c|}
\hline & \multicolumn{3}{|c|}{ Participant } & \multirow{2}{*}{ Total } \\
\hline & & & C & $\mathbf{H}$ & $\mathbf{P}$ & \\
\hline \multirow{10}{*}{ Q6 } & \multirow[b]{2}{*}{ A } & Count & 13 & 5 & 20 & 38 \\
\hline & & $\begin{array}{c}\text { \% within } \\
\text { Participant }\end{array}$ & $44.8 \%$ & $16.7 \%$ & $66.7 \%$ & $42.7 \%$ \\
\hline & \multirow[b]{2}{*}{ D } & Count & 1 & 0 & 0 & 1 \\
\hline & & $\begin{array}{c}\% \text { within } \\
\text { Participant }\end{array}$ & $3.4 \%$ & $0.0 \%$ & $0.0 \%$ & $1.1 \%$ \\
\hline & \multirow[b]{2}{*}{ NS } & Count & 7 & 6 & 5 & 18 \\
\hline & & $\begin{array}{c}\text { \% within } \\
\text { Participant }\end{array}$ & $24.1 \%$ & $20.0 \%$ & $16.7 \%$ & $20.2 \%$ \\
\hline & \multirow[b]{2}{*}{ SA } & Count & 6 & 19 & 5 & 30 \\
\hline & & $\begin{array}{c}\% \text { within } \\
\text { Participant }\end{array}$ & $20.7 \%$ & $63.3 \%$ & $16.7 \%$ & $33.7 \%$ \\
\hline & \multirow[b]{2}{*}{ SDA } & Count & 2 & 0 & 0 & 2 \\
\hline & & $\begin{array}{c}\% \text { within } \\
\text { Participant }\end{array}$ & $6.9 \%$ & $0.0 \%$ & $0.0 \%$ & $2.2 \%$ \\
\hline \multirow{2}{*}{\multicolumn{2}{|c|}{ Total }} & Count & 29 & 30 & 30 & 89 \\
\hline & & $\begin{array}{c}\% \\
\text { within } \\
\text { Participant } \\
\end{array}$ & $100.0 \%$ & $100.0 \%$ & $100.0 \%$ & $100.0 \%$ \\
\hline \multicolumn{7}{|c|}{ Table 3} \\
\hline
\end{tabular}


In the question of undergraduate training in pharmacology has equipped me to prescribe safely, among pharmacologists $73.3 \%$ agreed and $6.7 \%$ strongly agreed. But among clinical tutors, $37.9 \%$ agreed and $31 \%$ strongly agreed; $56.7 \%$ house staffs agreed and $23.3 \%$ not sure. $P$ value $>0.05$.

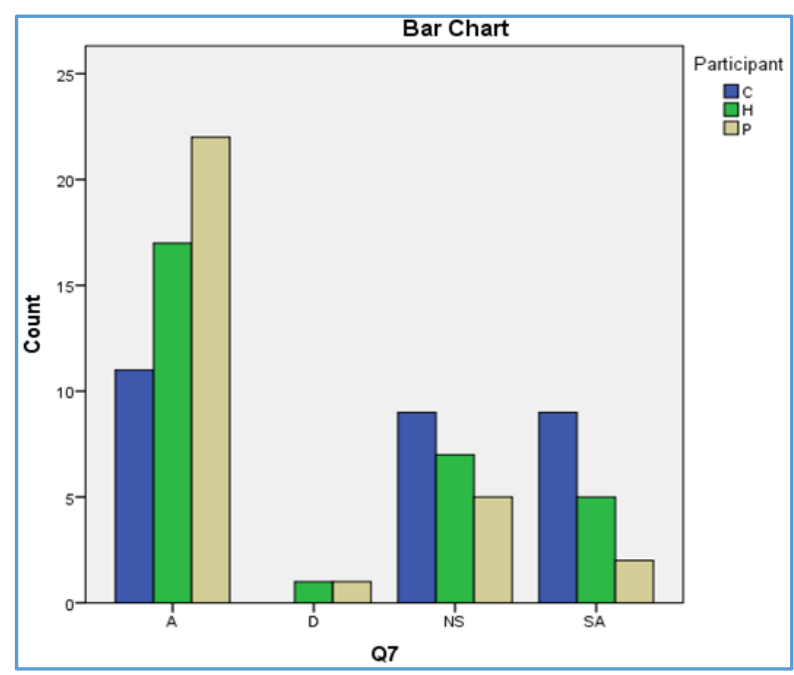

Fig. 3

In case of proposed curriculum, all the three groups agreed. In all questions of proposed curriculum, p value is $>0.05$ (not significant) except in the question of improved training could have prevented ADR. Here, $p$ value is 0.00 . Here, $33.3 \%$ junior doctors are not sure.

\begin{tabular}{|c|c|c|c|c|c|c|}
\hline & \multicolumn{3}{|c|}{ Participant } & \multirow{2}{*}{ Total } \\
\hline & & & C & H & $\mathbf{P}$ & \\
\hline \multirow{6}{*}{ Q13 } & \multirow[b]{2}{*}{ A } & Count & 12 & 8 & 23 & 43 \\
\hline & & $\begin{array}{c}\% \text { within } \\
\text { Participant }\end{array}$ & $41.4 \%$ & $26.7 \%$ & $76.7 \%$ & $48.3 \%$ \\
\hline & \multirow[b]{2}{*}{ NS } & Count & 3 & 10 & 0 & 13 \\
\hline & & $\begin{array}{c}\text { \% within } \\
\text { Participant }\end{array}$ & $10.3 \%$ & $33.3 \%$ & $0.0 \%$ & $14.6 \%$ \\
\hline & \multirow[b]{2}{*}{ SA } & Count & 14 & 12 & 7 & 33 \\
\hline & & $\begin{array}{c}\text { \% within } \\
\text { Participant }\end{array}$ & $48.3 \%$ & $40.0 \%$ & $23.3 \%$ & $37.1 \%$ \\
\hline \multirow{2}{*}{\multicolumn{2}{|c|}{ Total }} & Count & 29 & 30 & 30 & 89 \\
\hline & & $\begin{array}{c}\text { \% within } \\
\text { Participant }\end{array}$ & $100.0 \%$ & $100.0 \%$ & $100.0 \%$ & $100.0 \%$ \\
\hline
\end{tabular}

In the question of integration of Pharmacology with other clinical subjects, $37.9 \%$ clinicians agreed and 52.2\% strongly agreed, $33.3 \%$ junior doctors agreed and $50 \%$ strongly agreed and $36.7 \%$ pharmacologists agreed and $63.3 \%$ strongly agreed.

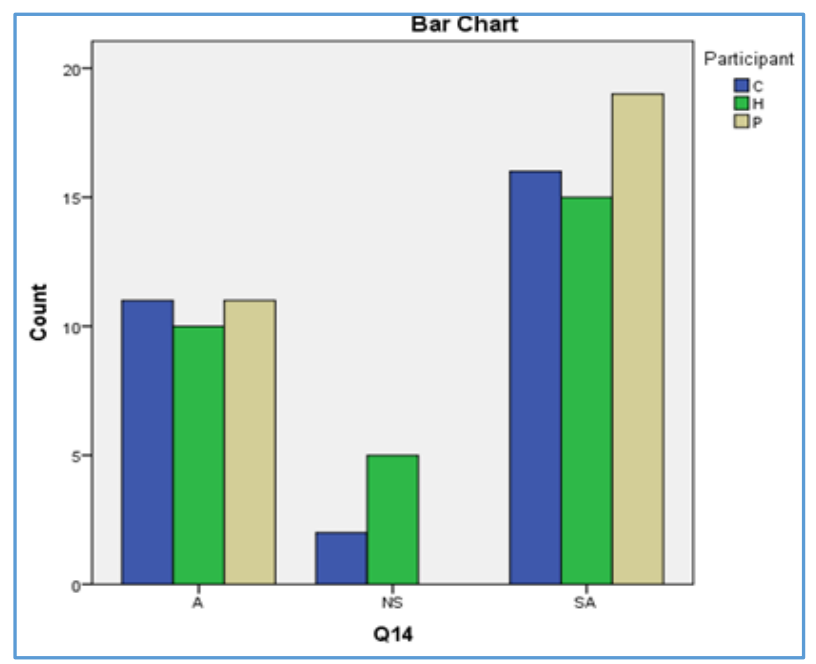

Fig. 4

\section{DISCUSSION}

It is very important to emphasize the academic need of reviewing the teaching programs from time to time and making adequate modifications to keep pace with progress in the subject and to cope with the requirements of the beneficiaries. In the present study, many interesting things came into picture and participants suggested many ways that could be incorporated in conventional pharmacology teaching, so as to make the subject more interesting and understandable.

This study was based on the opinion of pharmacologists, clinical tutors and junior doctors about the present undergraduate pharmacology curriculum with respect to its usefulness in clinics and to suggest certain changes if necessary.

Like our study, in a student's poll students wanted introduction of case studies and treatment as part of the regular teaching schedule and as many as $81 \%$ opined that pharmacology lectures should be more clinically oriented and case studies and treatment protocols to be added as a part of regular teaching in pharmacology.3; while in intern doctors' feedback study $32 \%$ interns pointed that incorporation of clinical pharmacology should be bed side learning. ${ }^{4}$ In our study $96.5 \%$ clinical tutors, $93.4 \%$ pharmacologists and all junior doctors are in favour of bedside study of pharmacology.

Some studies mentioned about the inability of doctors in writing rational prescription and it is suggested that there should be incorporation of some training of clinical pharmacology in the internship. ${ }^{5}$ In one study, student's attitude towards becoming pharmacologist was found unfavourable. This reflects their lack of knowledge about the subject scope and it may be their mindset to treat the subject as a very difficult one. Hence, they need to be well versed with the future prospective in the subject. By assisting the students in subject learning through simple and understandable illustrations, this mindset may be changed. ${ }^{6}$

Like our study, a study conducted in New Delhi, India, showed that $80.46 \%$ students and $87.50 \%$ teachers were in favour of bedside teaching of clinical pharmacology.7 In a pilot survey conducted by Vasundara et al, ${ }^{8}$ the majority of the interns (95\%) felt necessity for bedside clinical case study and the necessity of integrating pharmacology teaching with clinical subjects in MBBS phase-III, i.e. context learninggaining of knowledge and skills simultaneously.

Traditionally, it has focused more on factual information with little or no emphasis on clinical and applied aspects. Dispensing pharmacy and experimental pharmacology has remained the cornerstone of conventional pharmacology practical exercises. However, clinical utility and relevance of these practical exercises have always been questioned and criticized. 9 In our study, majority of subjects felt that dispensing pharmacy in practical was irrelevant and in place of it bedside case study should be incorporated.

In our study $97 \%$ clinical tutors, $96.7 \%$ pharmacologists and $86.6 \%$ junior doctors opined that distribution of handouts giving the outlines of topic before the lecture class. According to one study, students preferred lecture notes to be provided in the form of partial or complete handouts. ${ }^{2}$ (McLennan MW and Isaacs G, 2002). Hence, one solution for this can be the distribution of handouts of the class notes in advance (Say a week before the class). This method is very common in the western medical schools (Gene Prescott, East Carolina 
University, personal communication). Students get oriented to the topic in advance, can study the topic and come to the class with some important questions. This can definitely convert the one-sided lecture class into two-sided lecture with active interaction between the students and the teacher. Thus, the teacher will also get an enthusiasm to prepare well before going to the lecture class. This understanding has been well accepted by our students since $52 \%$ of the students 'strongly agree' and 23.4\% 'agree' with this concept.

Now if handouts are distributed before the class, then why should the students attend the class at all? This can be avoided by providing partial handouts, which the students can complete only if they attend the class.

There should be a continuous interaction between the clinicians and the pharmacologists at the level of teaching of pharmacotherapy, and pharmacology should be taught along with the clinical teaching (Ruckmani A, 2006).10 Introduction of Clinical Pharmacology in 4th year can also help in improving knowledge and learning of all medical students. ${ }^{11}$ In this study also majority of subjects are in favour of inclusion of some topic in final year.

In some study, the students expressed more need of case or problem-based studies, clinical orientations, innovative teaching programs, group discussions and tutorials in regular teaching, but they least liked seminar by them as was observed in other studies also. 12,13

In the same study by Advani et al (2006). ${ }^{14}$, 35\% of students want lectures on drug therapy in 3rd MBBS. This opinion of students also matches with Garg et al (2004). ${ }^{3}$ Our study further strengthens this concept since 93.1\% clinical tutors, $93.3 \%$ pharmacologists and $76.7 \%$ junior doctors agreed that some topic of pharmacology should be taught in final year again.

A gap in application of the theoretical knowledge is considered to be one of the reasons for occurrence of Adverse Drug Reaction (ADR) among patients. Prescribing errors are most common during internship due to various attributes focusing on lack of experience and shifting of priorities. ${ }^{15}$ resulting in harm to patients. ${ }^{16}$ We should try to make the seminars more interesting. The suggestions of relevant modifications in the current curriculum pharmacology made by Indian Pharmacology Society and in various research publications time to time. ${ }^{17-23}$

- With the present curriculum pharmacologists are satisfied, but clinical tutors and junior doctors are dissatisfied with the system.

- Existing curriculum mainly focused on theoretical aspect, so there is a gap between theoretical knowledge and its applications - probable cause of dissatisfaction.

- $\quad$ For proposed changes in curriculum, all the three groups agreed.

\section{CONCLUSION}

Training in Pharmacology should create expertise in rational and safe use of drugs. Clinicians felt that present training is not of sufficient help. Not only clinicians but also pharmacologists and junior doctors suggested some modifications including bedside teaching of pharmacology. A fresh and revised pharmacology curriculum, which is clinically oriented is the need of the hour.

\section{LIMITATION}

The students' feedback serves as an array of effective methodologies in pharmacology teaching. But students' opinion was not taken in this study.

\section{Annexe A}

\section{Questions are the following:}

Questionnaire - based on internationally accepted "Likert Scale"

1=Strongly Agree (SA), 2=Agree (A), 3=Not Sure (NS), 4=Disagree (D), 5=Strongly Disagree (SDA).

\section{For Assessment of Existing System of Teaching}

1. Undergraduate training in pharmacology has equipped me to prescribe rationally.

1=Strongly Agree (SA), 2=Agree (A), 3=Not Sure (NS), 4=Disagree (D), $5=$ Strongly Disagree (SDA).

2. I have enough knowledge about drugs used in medical emergencies.

1=Strongly Agree (SA), 2=Agree (A), 3=Not Sure (NS), 4=Disagree (D), $5=$ Strongly Disagree (SDA).

3. I have enough knowledge about antidotes in drug over dosage.

1=Strongly Agree (SA), 2=Agree (A), 3=Not Sure (NS), 4=Disagree (D), $5=$ Strongly Disagree (SDA).

4. I feel confident in making decisions on patient's drug therapy.

1=Strongly Agree (SA), 2=Agree (A), 3=Not Sure (NS), 4=Disagree (D), 5=Strongly Disagree (SDA).

5. I usually consult Pharmacology text book, while I find difficulty in prescribing some drugs.

1=Strongly Agree (SA), 2=Agree (A), 3=Not Sure (NS), 4=Disagree (D), $5=$ Strongly Disagree (SDA).

6. I usually consult text book of concerned subjects, while I find difficulty in prescribing some drugs.

1=Strongly Agree (SA), 2=Agree (A), 3=Not Sure (NS), 4=Disagree (D), $5=$ Strongly Disagree (SDA).

7. Undergraduate training in pharmacology has equipped me to prescribe safely.

1=Strongly Agree (SA), 2=Agree (A), 3=Not Sure (NS), 4=Disagree (D), $5=$ Strongly Disagree (SDA).

\section{Proposed Curriculum}

8. I feel bedside case study (a real clinical problem) in pharmacology practical would have been more relevant in patient care.

1=Strongly Agree (SA), 2=Agree (A), 3=Not Sure (NS), 4=Disagree (D), $5=$ Strongly Disagree (SDA)

9. It would be appropriate if some topics of Pharmacology are taught during final year again.

1=Strongly Agree (SA), 2=Agree (A), 3=Not Sure (NS), 4=Disagree (D), $5=$ Strongly Disagree (SDA)

10. There should be more emphasis on problem solving exercise rather than didactic lectures.

1=Strongly Agree (SA), 2=Agree (A), 3=Not Sure (NS), 4=Disagree (D), $5=$ Strongly Disagree (SDA)

11. There should be distribution of handouts giving the outlines of topic before the lecture class.

1=Strongly Agree (SA), 2=Agree (A), 3=Not Sure (NS), 4=Disagree (D), $5=$ Strongly Disagree (SDA) 
12. Relevance of dispensing pharmacy exercise knowledge (Preparing and dispensing of ointments, lotion, etc.) in patient's care is doubtful.

1=Strongly Agree (SA), 2=Agree (A), 3=Not Sure (NS), 4=Disagree (D), 5=Strongly Disagree (SDA)

13. I feel that improved training could have prevented ADR.

1=Strongly Agree (SA), 2=Agree (A), 3=Not Sure (NS), 4=Disagree (D), 5=Strongly Disagree (SDA)

14. I would like integration of Pharmacology with other clinical subjects.

\section{REFERENCES}

1. Mukopadhyay K. Relevance of pharmacology in the present context. Journal of Indian Medical Association 2005;103(1):40.

2. Mcmillan DE, Wenger GR. Effects of curriculum and format changes in a medical pharmacology course 1983 to 1987. J Med Educ 1987;62(10):836-41.

3. Garg A, Rataboli PV, Muchandi K. Students' opinion on the prevailing teaching methods in pharmacology and changes recommended. Indian J Pharmacol 2004;36(3):155-8.

4. Jaykaran, Chavda N, Yadav P, et al. Intern doctors' feedback on teaching methodologies in pharmacology. J Pharmacol Pharmacother 2010;1(2):114-6.

5. Han WH, Maxwell SR. Are medical students adequately trained to prescribe at the point of graduation? views of first year foundation doctors. Scott Med J 2006;51(4):2732.

6. Uma A Bhosale, Radha Yegnanarayan, Gauri E Yadav. Attitude, perception and feedback of second year medical students on teaching-learning methodology and evaluation methods in pharmacology: a questionnairebased study. Niger Med J 2013;54(1):33-9.

7. Kela AK, Mehta VL. Impact of inclusion of clinical projects in undergraduate teaching. Indian J Pharmacol 1993;25(4):249-50.

8. Vasundara K, Kanchan P, Pundarikaksha HP, et al. An imperative need to change pharmacology curriculum: a pilot survey. Indian J Pharmacol 2010;42(6):420.

9. Desai M. Changing face of pharmacology practicals for medical undergraduates. Indian J Pharmacol 2009;41(4):151-2.
10. Ruckmani A. The role of pharmacologists: present and future. IJP 2006;38(2):145-6.

11. Nierenberg DW, Therese AS. The effects of required fourth-year clinical pharmacology course on student attitudes and subsequent performance. Clin Pharmacol Ther 1986;40(5):488-93.

12. Chadav N, Yadav P, Chaudhri M, et al. Second year student's feedback on teaching methodology and evaluation methods in pharmacology. Natl J Physiol Pharm Pharmacol 2011;1(1):23-31.

13. Hariharan TS. Need for the changes in the practical pharmacology curriculum of medical graduates. Indian J Pharmacol 2004;36(3):181

14. Advani UP, Bhojani KG, Gada VP. VMGMC students view on the prevailing teaching methods in and pharmacology and changes recommended. Solapur medical Journal 2006;2:1-8.

15. Sallie-Anne P, Isobel R, Tony $\mathrm{S}$, et al. Intern prescribing decisions: few and far between. Education for health 2002;15(3):315-325.

16. Kazeem AO, Idowu OS, Amole OA. Interns' knowledge of clinical pharmacology and therapeutics after undergraduate and on-going internship training in Nigeria: a pilot study. BMC Medical education 2009;9:50.

17. Sharma R, Verma U, Kapoor B, et al. Novel teaching approaches in pharmacology. JK Sci 2004;6(3):172-3.

18. Bhavsar VH. Experience regarding modification of the teaching and evaluation pattern in practical pharmacology. Indian J Pharmacol 2004;36(6):385-6.

19. Mathur VS. Towards a more meaningful teaching a pharmacology. Indian J Pharmacol 2004;36(4):259-61.

20. Kausal S, Chopra SC, Arora S. Modifications in the undergraduate MBBS pharmacology practical curriculum: the DMCH model. Indian J Pharmacol 2007;39(1):57-9.

21. Sharma V, Sharma R. Pharmacolgy teaching: need for a sea change. Indian J Pharmacol 2009;41(6):288.

22. Joshi A, Trevedi M. Innovation in pharmacology teaching. Int J Pharm Biomed Res 2010;1(2):62-4.

23. Naeem SS, Rizvi W, Kumar A. Revisiting undergraduate practical pharmacology. J Pharmacol Pharmacother 2012;3(1):76-9. 